\title{
High-Mobility Group Box 1 Protein (HMGBI): Role in Lupus Nephritis
}

\author{
MERVAT ABO GABAL, M.D.*; HANAN FAROUK, M.D.*; NORAN O. EL AZIZI, M.D.*; \\ MARYAM A. ABDULRAHMAN, M.D.*; DALIA GAMAL, M.Sc.* and NEAMA M. LOTFY, M.D.** \\ The Departments of Internal Medicine \& Rheumatology* and Clinical Pathology**, Faculty of Medicine, Ain Shams University
}

\begin{abstract}
Background: According to recent studies, in renal disease High Mobility Group Box 1 protien (HMGB1) levels in blood and urine, its expression in renal tissue, and its levels in the cytoplasm and extracellular medium are all elevated.
\end{abstract}

Aim of Study: Was to assess serum and urinary levels of HMGB1 in correlation to renal histopathology, disease activity and organ damage in systemic lupus patients (SLE).

Patients and Methods: Serum and urine levels of HMGB1 were measured in 25 SLE patients with active nephritis by ELISA at baseline (I) and after 6 months follow-up (II). Renal biopsies were performed at baseline.

Results: There was high statistical significant difference between serum and urine HMGB 1 at baseline (I) and after follow-up (II) and between total BILAG score (I) and (II). There was statistically significant difference between SLE nephritis patients (responders and non responders) as regard total BILAG index, $p<0.001$. There was statistical significant difference between different classes of renal biopsy regarding urinary level of High Mobility Box protein 1 (I), $p<0.05$ with highest level in class V. At base line, there were no statistical difference between different categories of renal BILAG score as regard serum or urinary levels of high mobility box protein 1 (I), $p>0.05$. After follow-up, there was significant difference between patients with BILAG category A and C in serum (but not urinary) high mobility box protein 1 (II). There was significant positive correlation between total BILAG score after follow-up and serum level of High Mobility Box protein 1 (II) and SLICC score, $p<0.05$. There was a significant positive correlation between renal BILAG score after followup and serum High Mobility Box protein 1 (II) after followup. There was a significant positive correlation between 24hrs urinary proteins and urinary level of High Mobility Box protein 1 (II) after follow-up $p<0.05$.

Conclusion: HMGB 1 levels (serum and/or urinary) are high in SLE patients with nephritis compared to reference range. There is an association/correlation not only between HMGB1 and general disease activity in SLE patients but also between it and renal disease activity, severity and class. It

Correspondence to: Dr. Mervat Abo Gabal, The Department of Internal Medicine and Rheumatology, Faculty of Medicine, Ain Shams University could be a useful marker of lupus nephritis activity and class that may influence therapeutic strategies replacing rebiopsy.

Key Words: Lupus nephritis - High mobility group box 1 protien-Disease activity.

\section{Introduction}

SYSTEMIC Lupus Erythematosus (SLE) is an autoimmune disease characterized by the production of autoantibodies and multi-organ system involvement with a wide array of clinical manifestations [1]. It is characterized by presence of autoreactive $\mathrm{B}$ and $\mathrm{T}$ cells responsible for the aberrant production of broad and heterogenous group of auto antibodies [2].

Lupus nephritis (LN) is regarded as one of the most severe organ manifestations in SLE affecting approximately $35 \%$ to $50 \%$ of patients with lupus [3]. Conventional biomarkers for the determination of LN-proteinuria, protein/creatinine ratio in spot urine, $24 \mathrm{~h}$ urine proteinuria, creatinine clearance, doublechain anti-DNA levels, and serum complement, among others-have been extensively researched in LN. Nevertheless, these biomarkers may not be useful enough to appropriately predict relapse, accurately monitor response to treatment, or identify the degree of disease activity and chronic damage. For this reason, the investigation of new potential biomarkers that overcome these obstacles are clearly necessary [4].

Among the many antibodies potentially participating in the formation of immune complexes, antibodies against DNA are the hallmark of SLE. Recently, it has been shown that these DNAcontaining immune complexes constitute among others, high mobility group box Protein 1 (HMGB 1 ), which has been suggested to be involved in binding of these immune complexes to renal tissue and initiate renal injury [5]. 
High-Mobility Group Box 1 protein (HMGBl), a nuclear protein found in all mammalian cells, is known as a DNA-binding protein participating in chromatin structure and transcriptional regulation. Extracellular HMGB 1 has been identified as a proinflammatory mediator [6].

Strong expression levels of the receptors for HMGB, Receptors for Advanced Glycation End products (RAGE), Toll like receptors 2 (TOLL 2), Toll like receptors 4 (TOLL 4) were seen in kidney tissue from patients with active lupus nephritis, indicating that HMGB1 can exert its functions. These studies suggest that HMGB1 might serve as a marker of disease activity in SLE patients, especially in those with renal involvement [7].

\section{Aim of the study:}

The aim of this study is to assess serum and urinary levels of high mobility group box 1 protein in correlation to renal histopathology, disease activity and organ damage in systemic lupus patients.

\section{Patients and Methods}

The present study was a cross sectional and prospective study carried out on 25 patients with proved active lupus nephritis [8,9]. Patients were recruited from out patient Rheumatology Clinic and in patient Rheumatology department in Ain Shams Univeristy Hospital in the period between January - December 2016. Those with non lupus renal disease were excluded. After 6 months followup, 12 lupus nephritis patients showed remission (complete in 1 and partial in 11) and 12 patients were non responders [10]. For all patients, detailed history taking and thorough clinical and musculoskeletal examination were performed. Measurement of Erythrocyte Sedimentation Rate (ESR), C-Reactive Protein (CRP) was performed. C3 and C4 measured by immunochemical methods, ANA and Anti-dsDNA antibody by indirect immunoflourescene test with titre. Serum and urine levels of HMGB1 protein using ELISA at baseline and after 6 months follow-up (Detection range of the kit: 5ug/L-135ug/L). Renal biopsy with histopathology was performed at baseline. Disease activity of SLE was assessed by BILAG Index [11]. Accumulated damage was assessed by Systemic Lupus International Collaborative Clinics/American College of Rheumatology Damage Index (SLICC/ ACRDI) [12]. Serum and urine levels of HMGB1 protein were measured by ELISA at the start of the study and after 6 months follow-up [13]. Renal biopsy with histopathology was performed at baseline [14]. Oral consents were obtained from all participants after explaining the nature of the study. The study was approved by the Local Research Ethical Committee of Ain Shams University and conforms to the provisions of the Declaration of Helsinki in 1995.

\section{Statistical methodology:}

Analysis of data was done by personal computer using SPSS (Statistical Program for Social Science), description of quantitative variables as mean, Standard Deviation (SD) and range. Description of qualitative variables as number (no) and percentage. Chi-square test was used to compare qualitative variables, unpaired $t$-test was used to compare two independent groups as regard a quantitative variables. Mann Whitney test was used instead of $t$-test in non parametric data (SD more than 50\%). Spearman correlation co-efficient rank test was used to rank different variables against each other positively or inversely. $p>0.05=$ Insignificant. $p \leq 0.05=$ Significant. $p \leq$ than $0.001=$ Highly significant.

\section{Results}

This study was a cross sectional and prospective study that started with 25 SLE patients with nephritis and ended with 24 as one patient died.

At the beginning of the study constitutional symptoms were the commonest, affecting 25 patients $(100 \%)$ in the form of 14 patients $56 \%$ had fatigue, fever and weight loss, 5 patients $(20 \%)$ with fatigue and fever, 4 patients with fatigue and weight loss $(16 \%)$ and 2 patients with fatigue only $(8 \%)$, this was followed by polyarthralgia affecting $23(92 \%)$ patients, malar rash, photosensitivity affecting 20 patients $(80 \%)$, followed by alopecia affecting 18 patients (72\%), oral ulcers affecting 17 patients $(68 \%), 8$ patients $(32 \%)$ with pericardial effusion, 7 patients (28\%) with pleural effusion, 3 patients $(12 \%)$ were presented with fits, 3 patients (12\%) with carditis, 2 patients $(8 \%)$ were presented with polyarthritis and finally 1 patient $(4 \%)$ with interstitial fibrosis.

After 6 months follow-up, we had 2 nephritis groups: 12 patients in remission (complete remission in 1 and partial in 11) and 12 non responders patients.

All patients were on oral steroids at base line and after follow-up. All patients were on hydroquine at base line, after follow-up 23 patients only were on hydroquine (stopped in one due to retinal changes). All patients were on azathioprine at base line, after follow-up, only 6 patients were on azathioprine. No patients were on cellcept at base line 
while after follow-up 18 patients were on cellcept. All patients received pulse solumedrol at base line with 1 patient had received previous 6 cycles before the study. Also all patients received pulse endoxan with also 1 patient had received previous 6 cycles.

All patients (100\%) did renal biopsy, 11 (44\%) of them were class IIIA-C, 8 patients (32\%) were class IV and 6 patients (24\%) were class V. Actually we had 1 patient with renal biopsy showed class III-V mainly V and another one with class IV-V predominately $\mathrm{V}$. They were added to 4 patients with class $\mathrm{V}$ to have total class $\mathrm{V}$ biopsies of 6 . The activity index in the renal biopsy ranged from $1-14$ with mean \pm SD $(6.480 \pm 3.216)$ while the chronicity index ranged from 1-5 with mean \pm SD

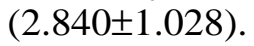

The assessment of disease activity was done using BILAG score, where A (the patient had severe disease), $\mathrm{B}$ (the patient had moderate disease), $\mathrm{C}$ (the patient had mild disease), D (disease in remission), E (the patient never had this system affected before).
The commonest system that showed residual organ damage after 6 months was the renal system in 6 patients $(25 \%)$, in the form of 3 patients with proteinuria greater than 3.5 gram $/ 24$ hours, 2 patients with proteinuria more than 3.5 gram $/ 24$ hours and estimated GFR less than $50 \mathrm{ml} /$ minute and 1 patient with estimated GFR less than $50 \mathrm{ml} /$ minute and had end stage renal disease. This was followed by neuropsychiatric damage in $5(20.83 \%)$ of the patients in the form of 3 patients with fits and 2 with cognitive dysfunction. Then cardiovascular and pulmonary damage in each $2(8.33 \%)$ of the patients where 1 patient was with cardiomyopathy, 1 patient with valvular disease, 1 patient had pulmonary infiltrate and 1 patient had interstitial pulmonary fibrosis, ocular damage occurred in one $(4.17 \%)$ of the patients with only 1 patient who had retinal changes, finally $1(4.17 \%)$ patient was presented with diabetes regardless of treatment, no patients were presented with peripheral vascular damage, gastrointestinal or musculoskeletal damage.

Table (1): Demographic and laboratory findings in the studied SLE patients at baseline and after follow-up.

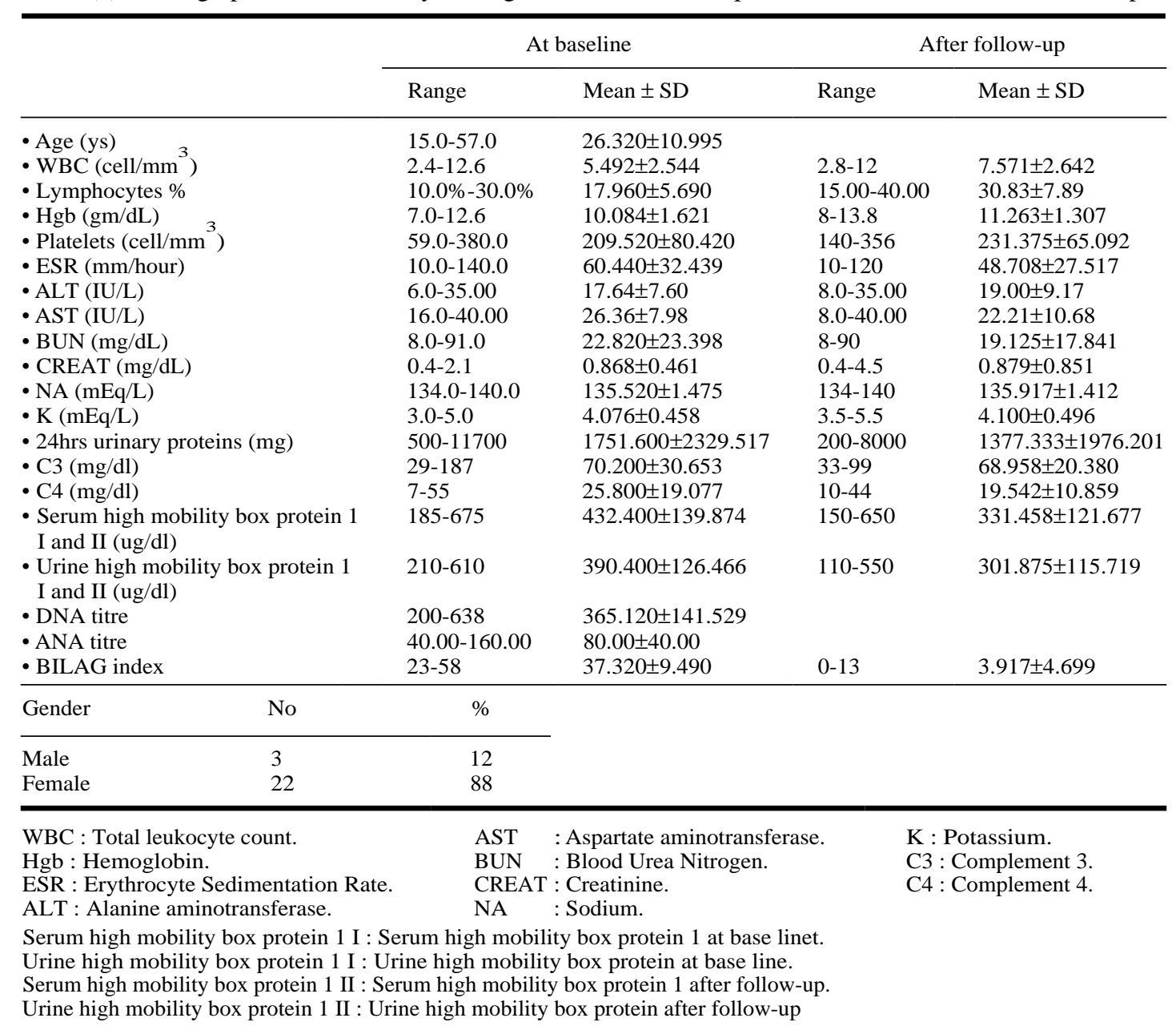


Table (2): BILAG score at base line and after 6 months followup among the studied SLE patients.

\begin{tabular}{|c|c|c|c|c|}
\hline & \multicolumn{2}{|c|}{ At baseline } & \multicolumn{2}{|c|}{ After follow-up } \\
\hline & $\mathrm{N}$ & $\%$ & $\mathrm{~N}$ & $\%$ \\
\hline \multicolumn{5}{|c|}{ Constitutional Bilag: } \\
\hline Category A & 24 & 96.00 & 0 & 0.00 \\
\hline Category B & 1 & 4.00 & 0 & 0.00 \\
\hline Category $\mathrm{C}$ & 0 & 0.00 & 0 & 0.00 \\
\hline Category D & 0 & 0.00 & 24 & 100.00 \\
\hline Category E & 0 & 0.00 & 0 & 0.00 \\
\hline \multicolumn{5}{|c|}{ Mucocutaneous Bilag: } \\
\hline Category A & 0 & 0.00 & 0 & 0.00 \\
\hline Category B & 20 & 80.00 & 0 & 0.00 \\
\hline Category $\mathrm{C}$ & 5 & 20.00 & 3 & 12.50 \\
\hline Category D & 0 & 0.00 & 21 & 87.50 \\
\hline Category E & 0 & 0.00 & 0 & 0.00 \\
\hline \multicolumn{5}{|c|}{ Neuropsychiatric Bilag: } \\
\hline Category A & 3 & 12.00 & 0 & 0.00 \\
\hline Category B & 1 & 4.00 & 0 & 0.00 \\
\hline Category $\mathrm{C}$ & 0 & 0.00 & 0 & 0.00 \\
\hline Category D & 0 & 0.00 & 4 & 16.67 \\
\hline Category E & 21 & 84.00 & 20 & 83.33 \\
\hline \multicolumn{5}{|c|}{ Musculoskeletal Bilag: } \\
\hline Category A & 0 & 0.00 & 0 & 0.00 \\
\hline Category B & 0 & 0.00 & 0 & 0.00 \\
\hline Category $\mathrm{C}$ & 25 & 100.00 & 5 & 20.83 \\
\hline Category D & 0 & 0.00 & 19 & 79.17 \\
\hline Category E & 0 & 0.00 & 0 & 0.00 \\
\hline \multicolumn{5}{|c|}{ Cardiorespiratory Bilag: } \\
\hline Category A & 6 & 24.00 & 0 & 0.00 \\
\hline Category B & 5 & 20.00 & 0 & 0.00 \\
\hline Category $\mathrm{C}$ & 0 & 0.00 & 0 & 0.00 \\
\hline Category D & 0 & 0.00 & 10 & 41.67 \\
\hline Category E & 14 & 56.00 & 14 & 58.33 \\
\hline \multicolumn{5}{|c|}{ Gastro intestinal Bilag: } \\
\hline Category A & 0 & 0.00 & 0 & 0.00 \\
\hline Category B & 0 & 0.00 & 0 & 0.00 \\
\hline Category $\mathrm{C}$ & 0 & 0.00 & 0 & 0.00 \\
\hline Category D & 0 & 0.00 & 0 & 0.00 \\
\hline Category E & 25 & 100.00 & 24 & 100.00 \\
\hline \multicolumn{5}{|c|}{ Ophthalmic Bilag: } \\
\hline Category A & 0 & 0.00 & 0 & 0.00 \\
\hline Category B & 1 & 4.00 & 0 & 0.00 \\
\hline Category C & 0 & 0.00 & 0 & 0.00 \\
\hline Category D & 0 & 0.00 & 1 & 4.17 \\
\hline Category E & 24 & 96.00 & 23 & 95.83 \\
\hline \multicolumn{5}{|l|}{ Renal Bilag: } \\
\hline Category A & 15 & 60.00 & 5 & 20.83 \\
\hline Category B & 10 & 40.00 & 1 & 4.17 \\
\hline Category C & 0 & 0.00 & 17 & 70.83 \\
\hline Category D & 0 & 0.00 & 1 & 4.17 \\
\hline Category E & 0 & 0.00 & 0 & 0.00 \\
\hline \multicolumn{5}{|c|}{ Haematological Bilag: } \\
\hline Category A & 0 & 0.00 & 0 & 0.00 \\
\hline Category B & 1 & 4.00 & 0 & 0.00 \\
\hline Category $\mathrm{C}$ & 15 & 60.00 & 1 & 4.17 \\
\hline Category D & 0 & 0.00 & 14 & 58.33 \\
\hline Category E & 9 & 36.00 & 9 & 37.50 \\
\hline
\end{tabular}

Table (3): Comparative study between serum/urinary level of High Mobility Box protein 1 and BILAG at base line (I) and after follow-up (II).

\begin{tabular}{|c|c|c|c|c|c|c|}
\hline & \multirow{2}{*}{ Range } & \multirow{2}{*}{$\begin{array}{c}\text { Mean } \pm \\
\text { SD }\end{array}$} & \multicolumn{2}{|c|}{$\begin{array}{c}\text { Paired } \\
\text { differences }\end{array}$} & \multicolumn{2}{|c|}{$\begin{array}{c}\text { Paired Samples } \\
\text { Test }\end{array}$} \\
\hline & & & Mean & SD & $t$ & $p$-value \\
\hline $\begin{array}{l}\text { - Serum high } \\
\text { mobility Box } \\
\text { protein } 1 \text { (I) }\end{array}$ & $\begin{array}{l}185- \\
675\end{array}$ & $\begin{array}{l}432.400 \\
\pm \\
139.874\end{array}$ & 107.917 & 101.531 & 5.207 & $<0.001 *$ \\
\hline $\begin{array}{l}\text { - Serum high } \\
\text { mobility Box } \\
\text { protein } 1 \text { (II) }\end{array}$ & $\begin{array}{l}150- \\
650\end{array}$ & $\begin{array}{l}331.458 \\
\pm \\
121.677\end{array}$ & & & & \\
\hline $\begin{array}{l}\text { - Urine High } \\
\text { Mobility }\end{array}$ & $\begin{array}{l}210- \\
610\end{array}$ & $\begin{array}{l}390.400 \\
\pm\end{array}$ & & & & \\
\hline $\begin{array}{l}\text { Box protein } \\
1 \text { (I) }\end{array}$ & & 126.466 & 93.333 & 100.679 & 4.542 & $<0.001 *$ \\
\hline - Urine High & $110-$ & 301.875 & & & & \\
\hline $\begin{array}{l}\text { Mobility } \\
\text { Box protein } \\
1 \text { (II) }\end{array}$ & 550 & 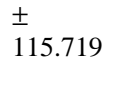 & & & & \\
\hline $\begin{array}{l}\text { - BILAG } \\
\text { Score at base }\end{array}$ & $\begin{array}{l}23- \\
58\end{array}$ & $\begin{array}{l}37.320 \\
\pm\end{array}$ & & & & \\
\hline line (I) & & 9.490 & 33.042 & 9.729 & 16.638 & $<0.001^{*}$ \\
\hline $\begin{array}{l}\text { - BILAG } \\
\text { Score after } \\
\text { follow-up } \\
\text { (II) }\end{array}$ & $\begin{array}{l}0- \\
13\end{array}$ & $\begin{array}{l}3.917 \\
\pm \\
4.699\end{array}$ & & & & \\
\hline
\end{tabular}

Comparative study between serum and urinary levels of High Mobility Box protein 1 (I) and (II) revealed high significant statistical difference. Also there was high statistical significant difference between total BILAG score (I) and (II) with $p$ value $<0.001 *$.

Table (4): Comparison between SLE responders and non responders as regard serum and urine high mobility box protein 1 (II) and BILAG score (II).

\begin{tabular}{|c|c|c|c|c|}
\hline & \multicolumn{2}{|c|}{ Renal response after follow-up } & \multicolumn{2}{|c|}{$t$-test } \\
\hline & $\begin{array}{l}\text { Non responders } \\
\text { (12) }\end{array}$ & Remission (12) & $t$ & $\begin{array}{c}p- \\
\text { value }\end{array}$ \\
\hline \multicolumn{5}{|c|}{$\begin{array}{l}- \text { Serum high } \\
\text { mobility box } \\
\text { protein } 1 \text { (II): }\end{array}$} \\
\hline Range & $175-650$ & $150-435$ & 0.963 & 0.346 \\
\hline Mean \pm SD & $355.417 \pm 138.785$ & $307.500 \pm 102.192$ & & \\
\hline \multicolumn{5}{|c|}{$\begin{array}{l}\text { - Urine high } \\
\text { mobility box } \\
\text { protein } 1 \text { (II): }\end{array}$} \\
\hline $\begin{array}{l}\text { Range } \\
\text { Mean } \pm \text { SD }\end{array}$ & $\begin{array}{l}175-550 \\
323.333 \pm 127.642\end{array}$ & $\begin{array}{l}110-435 \\
280.417 \pm 103.451\end{array}$ & 0.905 & 0.375 \\
\hline \multicolumn{5}{|c|}{$\begin{array}{l}\text { - BILAG Score } \\
\text { after follow- } \\
\text { up (II): }\end{array}$} \\
\hline Range & $1-13$ & $0-2$ & 3.846 & $0.001 *$ \\
\hline Mean \pm SD & $6.833 \pm 5.237$ & $1.000 \pm 0.426$ & & \\
\hline
\end{tabular}

After follow-up, there was decrease in both serum and urinary HMGB-1 levels in SLE nephritis patients in remission compared to resistant active nephritis but values did not reach statistical significance $p>0.05$. There was statistically significant difference between SLE nephritis patients (respond- 
ers and non responders) as regard total BILAG index, $p<0.001$, a finding reflecting coincidence between good response in both total disease and renal activity.

Table (5): Comparison between differrent classes of nephritis as regard serum and urine high mobility box protein 1 (I).

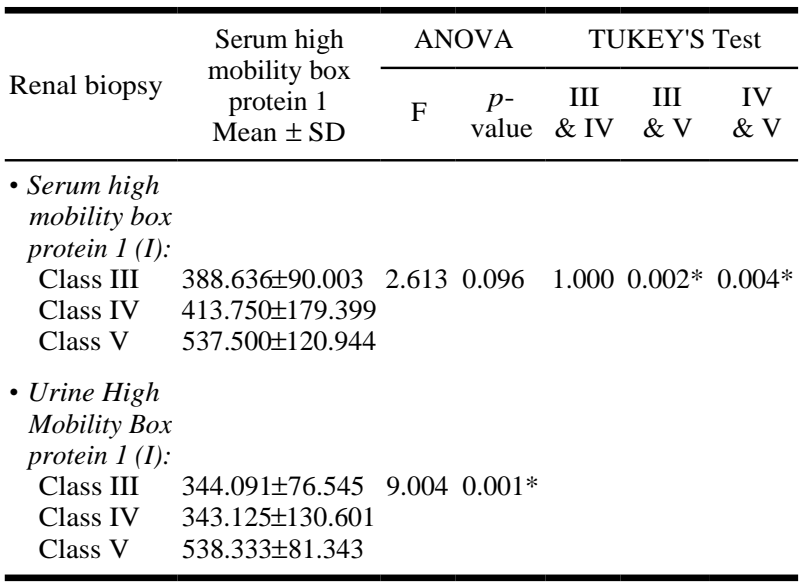

There was no stastistical significant difference between different classes of renal biopsy and serum level of high mobility box protein 1 (I) despite highest values in class $\mathrm{V}$ renal biopsy. However, there was statistical significant difference between different classes of renal biopsy regarding urinary level of High Mobility Box protein 1 (I), $p<0.05$. Further study by TUKEY'S Test showed significant difference in level of HMGB-1 between class V versus classIII and IV with highest level in class $\mathrm{V}$.

Table (6): Comparison between different categories of renal BILAG as regard serum and urinary level of high mobility box protein 1 (I) and (II).

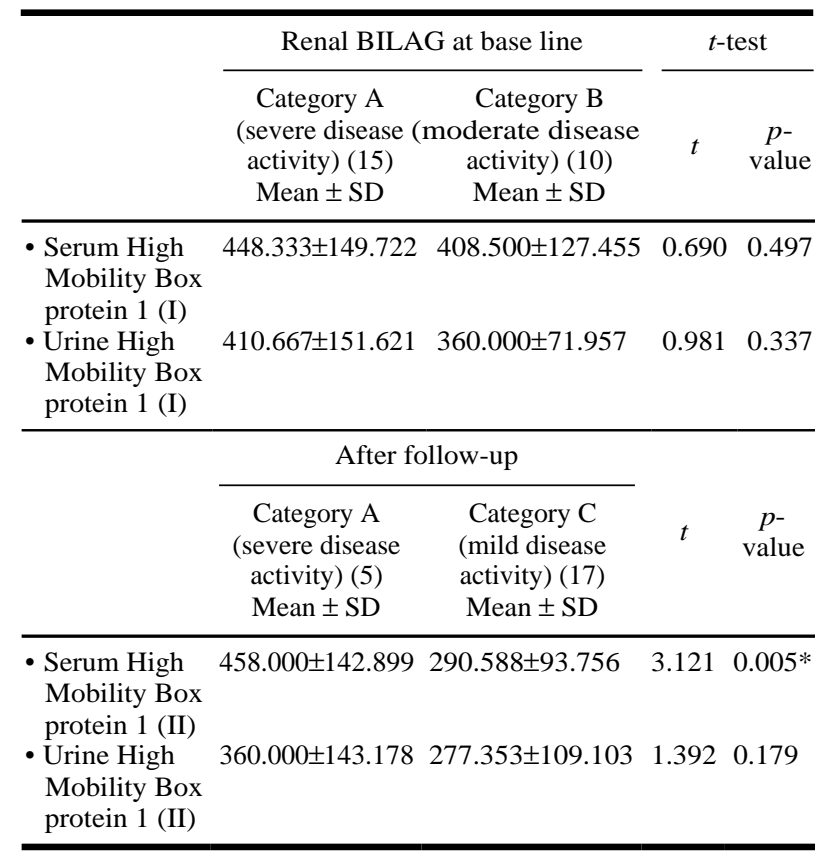

At baseline, there were no statistical difference between different categories of renal BILAG score as regard serum or urinary levels of high mobility box protein 1 (I), $p>0.05$, despite being higher in category A compared to category B. After followup, for statistical purposes, patients were classified according to renal BILAG, category A and C, there was significant difference between them in serum (but not urinary, despite being higher in category A compared to category $\mathrm{C}$ ) high mobility box protein $1 \mathrm{II}$.

There was no statistical significant difference in either serum or urinary High Mobility Box protein 1 between males and females SLE patients with $p>0.05$. (Data not shown).

Comparative study of the level of serum and urinary High Mobility Box protein 1 (I) between patients with and without different clinical manifestations revealed no stastistically significant difference with $p$-value $>0.05$ regarding malar rash, photosensitivity, oral ulcers, alopecia, constitutional symptoms, musckloskeletal affection, neuropsychiatric, cardiac, pulmonary and serositis. (Data not shown).

Table (7): Correlation between total/renal BILAG score (II) and serum, urinary level of High Mobility Box protein 1 (II) and SLICC score after follow-up.

\begin{tabular}{lcc}
\hline Total Bilag score (II) & $r$-value & $p$-value \\
\hline Serum level of High Mobility Box protein 1 (II) 0.471 & 0.020 \\
Urinary level of High Mobility Box protein 1 (II) $\begin{array}{c}0.255 \\
0.228 \\
\text { SLICC score }\end{array}$ & $\begin{array}{l}0.584 \\
\text { O.OO3* }\end{array}$ \\
\hline Renal BILAG score after follow-up & $r$ & $p$-value \\
\hline Serum High Mobility Box protein 1 (II) & 0.516 & O.O1O* \\
Urine High Mobility Box protein 1 (II) & 0.298 & 0.158 \\
\hline
\end{tabular}

There was significant positive correlation between total BILAG score after follow-up and serum level of High Mobility Box protein 1 (II) and SLICC score, $p<0.05$. There was a significant positive correlation between renal BILAG score after follow-up and serum High Mobility Box protein 1 (II) after follow-up.

There was a significant positive correlation between $24 \mathrm{hrs}$ urinary proteins after follow-up and urinary level of High Mobility Box protein 1 (II) after follow-up $p<0.05$. There was negative correlation between ANA titre and serum High Mobility box protein 1 (I) (data not shown). However, there was no correlation between renal BILAG score at base line and serum or urinary levels of High Mobility Box protein 1 (I) $p>0.05$. There was no significant correlation between level of High Mo- 
bility Box protein 1 in serum or urine at base line or after follow-up and SLICC score. (Data not shown).

Also, there was no significant correlation between age, certain labs at base line as CBC, ESR, kidney functions, protein creatinine ratio in urine, $\mathrm{C} 3$ and $\mathrm{C} 4$, activity and chronicity indices of renal biopsy and levels of serum or urinary High Mobility Box protein 1 (I) at base line $p>0.05$. (Data not shown).

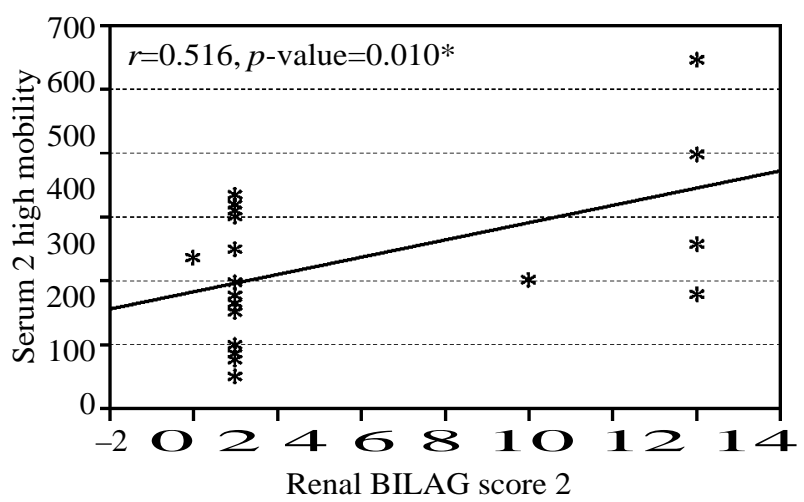

Fig. (1): Correlation between renal BILAG score after followup and serum High Mobility Box protein 1 II after follow-up.

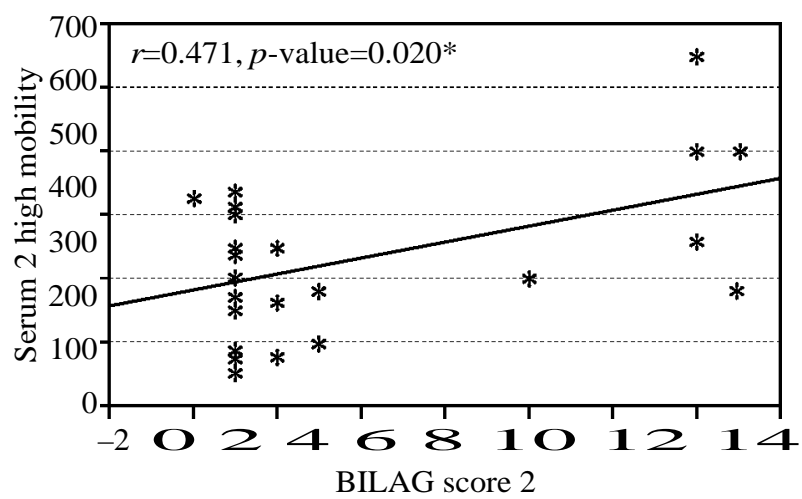

Fig. (2): Correlation between total BILAG score after followup and serum High Mobility Box protein 1 II after follow-up.

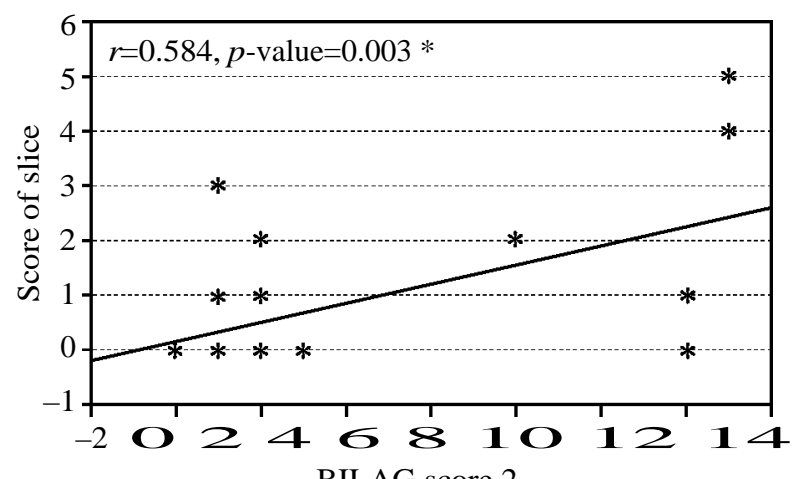

BILAG score 2

Fig. (3): Correlation between BILAG score after follow-up and SLICC score.

\section{Discussion}

Systemic Lupus Erythematosus (SLE) is an autoimmune disease affecting predominately women. It is characterized by various clinical manifestations, among these manifestations, renal involvement. Lupus nephritis is regarded as one of the most severe organ manifestations in SLE affecting approximately $35 \%$ to $50 \%$ of patients with lupus therefore, it is very important to explore pathogenesis and search for new therapeutic strategies to improve life quality of the patients [2].

It has been believed that B cells are multicolonally activated, which results in development of many antibodies, increase of immune complex, composure of circulating immune complex and deposition of in situ circulating immune complex in different parts of kidney and eventually injury of renal function. Recent evidence has revealed that many cytokines may be involved in lupus nephritis and the balance between proinflammatory cytokines and anti inflammatory cytokines play an important role in the immune response [5].

High Mobility Group Protein Box 1 (HMGBl), an intranuclear architerctural protein is well known for its nuclear function. Recently it has been identified as a potent proinflammatory cytokine it has been showed that HMGB1 was produced passively by injured or necrotic but not apoptotic cells, functions as a major stimulus of necrosis-induced inflammation. It could also control the activation and chemotaxis of inflarnmatory cells, and stimulate proinflammatory cytokine synthesis in inflammatory cells. Thus it has been reported that HMGB1 was involved in pathogenesis of lupus nephritis [15].

However, the renal expression in kidney tissues of lupus nephritis patients and the correlation between HMGB-1 and the SLE Active Index (AI), Chronicity Index (CI), pathological type of lupus nephritis is still unclear.

The aim of this study was to assess serum and urinary levels of HMGB-1 in correlation to renal histopathology, disease activity and organ damage in SLE patients with active nephritis.

This study was conducted on 25 SLE patients with nephritis all of them fulfilled the ACR 1982 revised criteria for classification of SLE [8]. Their age ranged from 15-57 years, they were 22 females and 3 males. All of them were recruited from Rheumatology Outpatient Clinic and Inpatient Department at Ain Shams University Hospitals. 
In this study levels of serum and urinary High Mobility box protein 1 were measured both at base line and after 6 months follow-up. Levels of serum and urinary High Mobility Box protein 1 were high among the studied patients at base line as regard it's reference range, with a significant difference when compared to their levels after follow-up. This partially agreed with the study of Zickert et al., [3] who found that there was a trend toward slightly decreased HMGB 1 levels at follow-up (mean of $101.7 \pm 50.7 \mathrm{ng} / \mathrm{mL}$, median of 99.7 , range of 27.9 to 183.9 ) however ( $p$-value not significant).

No correlation or association was found between demographic data of patients as regard age or sex and levels of both serum and urinary High Mobility Box protein 1 at the beginning of the study, this agreed with Wirestam et al., [16] who also did not find a relation between age, sex of the patients and High Mobility Box protein 1.

Also this study did not detect an association as regard different clinical manifestations of the patients at the beginning of the study as (malar rash, photosensitivity, alopecia, oral ulcers, arthritis, serositis, cardiac, pulmonary and CNS affection) and levels of both serum and urinary High Mobility Box protein 1, this agreed with Wirestam et al., [16] who also did not find a relation between them.

As regard the correlation between general disease activity and serum, urinary levels of High Mobility Box protein 1. No correlation was found between them at base line but after follow-up the study revealed a positive correlation between general disease activity using BILAG score and serum High Mobility box protein 1 . This agreed with almost all of the studies done in this field, however most of the studies done used the SLEDAI score as a measure of disease activity.

The study done by Liu et al., in 2015 [17] and Liu et al., in 2020 [1] found a positive correlation between serum, renal tissue expression of HMGB1 and SLEDAI score, which suggested that HMGB1 relates with the activity of the disease.

Also the study by Abdullahad et al., [5] found a positive correlation between urinary level of high mobility box protein 1 and SLEDAI score.

The Egyptian study by Badway et al., [18] found that Plasma and urinary HMGB1 and renal tissue levels HMGB1 levels correlated with SLEDAI.

As an LN biomarker, HMGB 1 serum levels are high in SLE patients with renal involvement compared with SLE patients without renal manifesta- tions. Certainly, the cytoplasmic and extracellular presence of HMGB1 has been found in kidney biopsies of patients with LN HMGB1 can be detected in the urine of patients with LN compared with that of patients without active LN. Additionally, it is positively correlated with serum levels of HMGB1, proteinuria, and SLEDAI [4].

Also, Tanaka et al., [19] found that serum HMGB 1 and IFN $\alpha$ were significantly higher in patients with active SLE (SLE Disease Activity Index (SLEDAI) score $\geq 6$ ) compared with healthy donors or patients with inactive SLE.

As regard the association or correlation between renal disease activity using renal BILAG score and levels of both serum and urinary High Mobility Box protein 1. At base line, no significant association was found between them, this could be explained as all patients had high renal disease activity at the beginning in the form of category (A) severe disease and category (B) moderate disease only with no patients with mild nephritis or nephritis in remission to allow better comparison, however the levels of High Mobility Box protein 1 were higher among patients with category A compared to patients with category B.

After 6 months of follow-up, the study showed significant association between degree of severity of nephritis and levels of serum HMGB 1 where patients with persistant severe disease activity category A showed significantly higher levels compared to patients with mild renal disease activity category $\mathrm{C}$.

The levels of both serum and urinary High mobility box protein 1 were high among non responders when compared to patients in remission although it did not reach statistical significance a finding that may reflect an association between HMGB1 and severity or activity of nephritis.

This agreed with the study of Zickert et al., [3] who found that patients at follow-up with (BILAG C/D), had lower serum levels of HMGB1 (mean of $93.7 \pm 54.2 \mathrm{ng} / \mathrm{mL}$, median of 94.0 , range of 27.9 to 181.5 ) versus those with persisting renal BILAG A or B (mean of $107.4 \pm 49.0 \mathrm{ng} / \mathrm{mL}$, median of 108.8 , range of 40.3 to 183.9 ), but the difference was not statistically significant [3].

Also a positive correlation was found between proteinuria and urinary levels of HMGB-1 at follow-up, this agrees with the study of both Abdulahad et al., [5] and Jog et al., [20] who found a correlation between degree of proteinuria and urinary levels of High Mobility Box protein 1, 
again a finding that reflects the association between HMGB1 and activity of nephritis as Proteinuria is commonly used as a biomarker for activity in LN. However some recent studies demonstrated a persistent histopathological renal activity despite apparent clinical quiescent disease (mild proteinuria) in a substantial proportion of patients. In contrast, no active inflammatory lesions in repeat biopsies were present in a group of patients with clinically poor therapeutic response. The clinical and histopathological findings were thus highly discordant [10].

This signified the importance of novel biomarkers for renal disease activity as HMGB1, since high levels of serum, urinary HMGB 1 combined with its expression in renal tissue reflect an ongoing inflammatory activity even in patients with quiescent clinical picture. This was proved by some studies as (Zickert et al., [3] who found that after follow-up, high serum levels of HMGB1 combined with renal tissue expression were found among patients with non histopathological response despite some of them were with quiescent clinical picture.

As regard the other labs, there were no correlation between (CBC, ESR, C3, C4, kidney functions, anti DNA titre) and serum, urinary levels of HMGB-1. This agreed with the study of both Zickert et al., [2] and Liu et al., [17]. However the study of Abdulahad et al., [5] on urine levels of HMGB1 in SLE patients with and without renal manifestations, revealed a negative correlation between complement levels and urinary levels of HMGB1. Also the study of Wirestam et al., [16] showed a correlation between anti DNA titre, complement levels and serum and urinary HMGB-1.

Our study showed no correlation between activity or chronicity indices of renal biopsy and serum or urinary levels of HMGB-1 this disagrees with the study of Liu et al., [17] who found a positive correlation between activity index and serum HMGB-1, and negative correlation as regard the chronicity index. While the study of Zickert et al., [3] showed an inverse relation between levels of serum and urinary High Mobility Box protein 1 and activity index at base line. This discrepancy could be related to that the studied populations were not comparable as regard the number of the patients and the methods used to measure High Mobility Box protein 1.

In our study possible association was found between levels of urinary High Mobility Box protein 1 and class $\mathrm{V}$ of lupus nephritis, this totally agrees with the study of Jog et al., [20] who found that levels of HMGB-1 were associated with LN class, and higher levels of urinary HMGB-1 were seen in patients with class $\mathrm{V}$ when compared to both proliferative and mixed classes. Therefore, high urinary HMGB-1 may be suggestive of membranous LN and warrants further evaluation in a large lupus cohort.

On the other hand, the study of both Zickert et al., [3] and Liu et al., [17] revealed no correlation between renal tissue expression of high mobility box protein 1 and class of lupus nephritis.

No correlation was found between organ damage using SLICC/ACR damage score and serum or urinary levels of HMGB-1, this agreed with the study of Wirestam et al., [16] who also found no correlation between end organ damage among the studied patients and levels of serum or urinary HMGB-1.

We conclude that HMGB1 levels (serum and/or urinary) are high in SLE patients with nephritis compared to reference range. There is an association /correlation not only between HMGB1 and general disease activity in SLE patients but also between it and renal disease activity, severity and class. It could be a useful marker of lupus nephritis activity and class that may influence therapeutic strategies replacing rebiopsy.

\section{References}

1- LIU T., SON M. and DIAMOND B.: HMGB1 in Systemic Lupus Erythematosus. Frontiers in Immunology, 11: Article 1057, 2020.

2- COZZANI E., DROSERA M., GASPARINI G., et al.: Serology of lupus erythematosus: Correlation between immunopathological features and clinical aspects. Autoimmune Dis. Article ID: 321359, 2014.

3- ZICKERT A., PALMBLAD K., SUNDELIN B., et al.: Renal expression and serum levels of high mobility group box 1 protein in lupus nephritis. Arthritis Res. Ther., 14: R36, 2012.

4- ARAGON C., TAFÚR R.A., ANA S.A., et al.: Urinary biomarkers in lupus nephritis. Journal of Translational Autoimmunity 3, 100042. https://doi.org/10.1016/ j.jtauto.2020.100042, 2020.

5- ABDULAHAD D.A., WESTRA J., BIJZET J., et al.: Urine levels of HMGB1 in Systemic Lupus Erythematosus patients with and without renal manifestations. Arthritis Res. Ther., 14: R184, 2012.

6- ANDERSSON U. and HARRIS H.E.: The role of HMGB1 in the pathogenesis of rheumatic disease. Biochim. Biophys. Acta., 1799: 141-8, 2010.

7- MA C., JIAO Y.L., ZHANG J., et al.: Elevated plasma level of HMGB1 is associated with disease activity and combined alterations with IFN-alpha and TNF-alpha in 
systemic lupus erythematosus. Rheumatol. Int., 32: 395402, 2012.

8- HOCHBERG M.C.: Updating the American College of Rheumatology revised criteria for the classification of systemic lupus erythematosus. Arthritis Rheum., 40 (9): $1725,1997$.

9- DOOLEY M.A., ARANOW C. and GINZLER E.M.: review of ACR renal criteria in SLE: 13 (11): 857-60, 2004.

10- ZICKERT A., SUNDELIN B., SVENUNGSSON E., et al.: Role of early repeated renal biopsies in lupus nephritis. Lupus Sci. Med., 1-18, 2014.

11- ISENBERG D.A., RAHMAN A., ALLEN E., et al.: BILAG 2004. Development and initial validation of an updated version of the British Isles Lupus Assessment Group's disease activity index for patients with systemic lupus erythematosus. Rheumatology, 44: 902-6, 2005.

12- GLADMAN D.D., UROWITZ M.B., ONG A., et al.: Lack of correlation among the 3 outcomes describing SLE: Disease activity, damage and quality of life. Clin. Exp. Rheumatol., 14: 305-8, 1996.

13- YAMADA S., INOUE K., YAKABE K., et al.: High mobility group protein 1 (HMGB1) quantified by ELISA with a monoclonal antibody that does not cross-react with HMGB2. Clinical Chemistry, 49 (9): 1535-7, 2003.

14- WEENING J.J., D'AGATI V.D., SCHWARTZ M.M., et al.: Classification of glomerulonephritis in systemic lupus erythematosus revisited. Kidney Int., 65: 521-30, 2004.

15- SCHAPER F., WESTRA J. and BIJL M.: Recent Developments in the Role of High-Mobility Group Box 1 in Systemic Lupus Erythematosus. Mol. Med., 20 (1): 729, 2014.

16- WIRESTAM L., SCHIERBECK H., SKOGH T., et al.: Antibodies against High Mobility Group Box protein-1 (HMGB1) versus other anti-nuclear antibody finespecificities and disease activity in systemic lupus erythematosus, Arthritis Research \& Therapy, (17), 338, 2015.

17- LIU Z., ZHANG H., C. XING, et al.: Multitarget therapy for induction treatment of lupus nephritis a randomized trial multitarget therapy for induction treatment of lupus nephritis. Annals of Internal Medicine, 162 (1): 18-26, 2015.

18- BADAWY A., SALAM R., FOUAD H., et al.: HMGB 1 Early Marker in Lupus Nephritis. Arthritis \& Rheumatology, 67: 2232-3, 2015.

19- TANAKA A., ITO T., KIBATA K., et al.: Serum highmobility group box 1 is correlated with interferon- $\alpha$ and may predict disease activity in patients with systemic lupus erythematosus. LUPUS, 28: 1120-7, 2019.

20- JOG N.R., BLANCO I., LEE I., et al.: Urinary highmobility group box-1 associates specifically with lupus nephritis class V; Lupus, 25 (14): 1551-7, 2016.

\section{مستوى بروتين (1) ذو التحرك العالى فى الدم والبول للى المرضى الهصابين بإلتهاب الكلى الهناعى الناتج عن مرض التهرئ الذئبة الحمراء}

وفقاً لللدراسات الحديثة فإنه فى إصابة الكلى يكون مستوى بروتين ا ذو التصرك العالى فى الدم والبول وفى نسيج الكلى وداخل وخارج

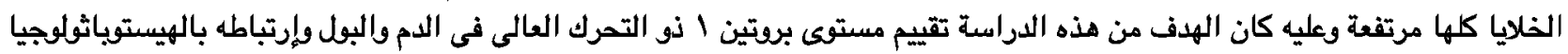

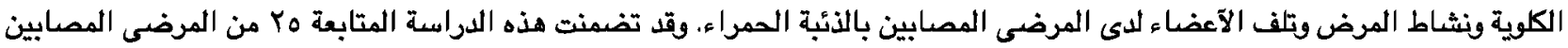

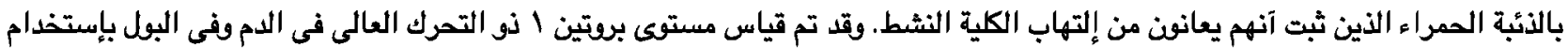

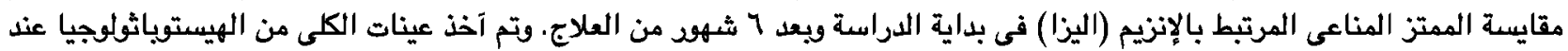

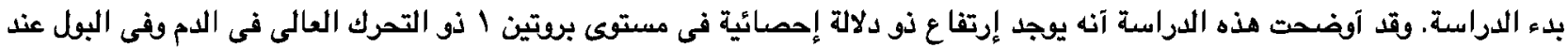

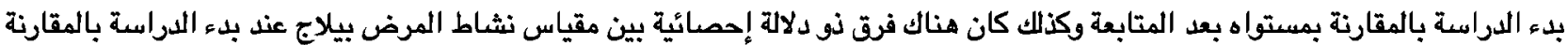

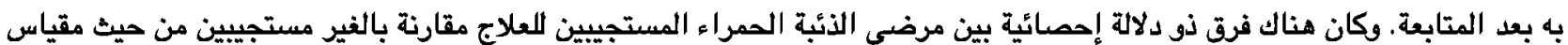

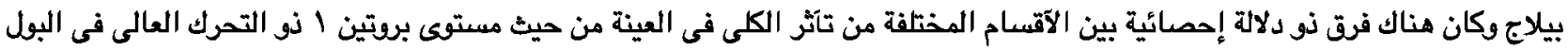

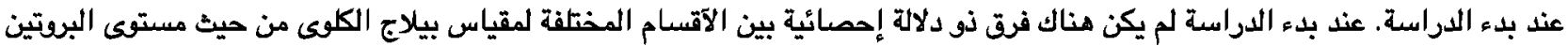

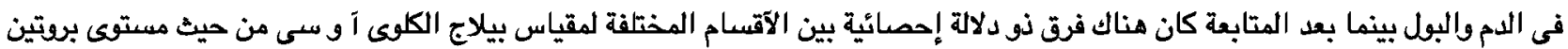

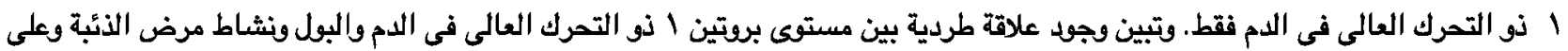

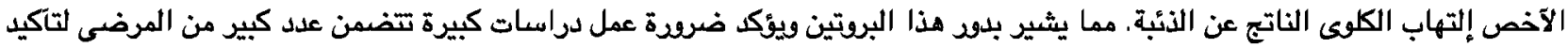

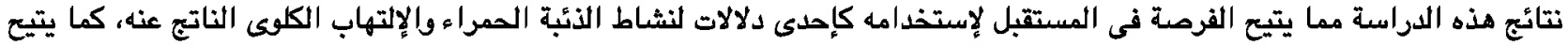

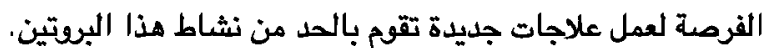

